\title{
ПОРІВНЯЛЬНА ОЦІНКА ЯКОСТІ ЖИТТЯ ПАЦІЄНТІВ, ЯКІ ОТРИМУЮТЬ НИРКОВУ ЗАМІСНУ ТЕРАПІЮ, ПРИ ВИКОРИСТАННІ СТАНДАРТНИХ ТА ІНДИВІДУАЛЬНИХ ПРОГРАМ ЛІКУВАННЯ
}

\author{
Національна медична академія післядипломної освіти імені П. А. Шупика
}

Вивчено основні параметри якості життя пацієнтів із хронічною хворобою нирок (XXH), які отримують замісну ниркову терапію, їх зв'язок із методикою проведення діалізу. Зроблено висновки про необхідність подальшого вивчення кореляційних зв'язків уремічних, гематологічних показників із показниками якості життя та розроблення математичних моделей індивідуальних діалізних програм.

Ключові слова: хронічна хвороба нирок, замісна ниркова терапія, якість життя, математична модель.

\section{СРАВНИТЕЛЬНАЯ ОЦЕНКА КАЧЕСТВА ЖИЗНИ ПАЦИЕНТОВ, ПОЛУЧАЮЩИХ ЗАМЕСТИТЕЛЬНУЮ ПОЧЕЧНУЮ ТЕРАПИЮ, ПРИ ИСПОЛЬЗОВАНИИ СТАНДАРТНЫХ И ИНДИВИДУАЛЬНЫХ ПРОГРАММ ЛЕЧЕНИЯ}

\author{
И. Л. Кучма \\ Национальная медицинская академия последипломного образования \\ имени П. А. Шупика
}

\begin{abstract}
Изучены основные параметры качества жизни пациентов с хронической болезнью почек (ХБП), получающих заместительную почечную терапию, их связь с методикой проведения диализа. Сделаны выводы о необходимости дальнейшего изучения корреляционных связей уремических, гематологических показателей с показателями качества жизни и разработки математических моделей индивидуальных диализных программ.
\end{abstract}

Ключевые слова: хроническая болезнь почек, почечная заместительная терапия, качество жизни, математическая модель.

\section{COMPARATIVE EVALUATION OF QUALITY OF THE PATIENTS' LIFE RECEIVING RENAL REPLACEMENT THERAPY WITH STANDARD AND CUSTOMIZED TREATMENT PROGRAMS}

\author{
National Medical Academy of Post-Graduate Education by $P$. L. Shupyk
}

\begin{abstract}
Improvement of methods of renal replacement therapy (RRT), chronic kidney disease (CKD), in particular, the use of modern dialysis technology, the introduction into clinical practice of new methods of providing adequate and gentle treatment led to a significant increase in the life expectancy of patients. At the same time, comes to the fore the problem of quality of life (QOL) of patients. Therefore, the approach of QoL parameters in patients with CKD receiving RRT, to the level of a healthy population is one of the main goals of modern nephrology. In this context, it becomes urgent the choice of method and technique of dialysis. The author studied the basic parameters of the quality of life of patients receiving renal replacement therapy, their relationship to the method of dialysis. The conclusions about the need for further study of correlations uremic, hematological parameters with quality of life and the development of mathematical models of individual dialysis programs.
\end{abstract}

Key words: chronic kidney disease, renal replacement therapy, quality life, mathematical model.

Вступ. Останнім часом серед хворих із хронічною хворобою нирок (ХХН), які перебувають на програмному гемодіалізі, спостерігається виражена тенден- ція до збільшення тривалості життя. Це пов'язано із значним покращанням техніки проведення хронічного гемодіалізу (ХГД). Значне продовження тривалості 
життя пацієнтів цієї групи вимагає вирішення питань покращення якості їх життя. Одним із методів досягнення цієї мети є компенсація метаболічних та гормональних порушень, що виникають при ХХН. За допомогою інтермітуючого гемодіалізу за короткий час корегують уремічні порушення, однак у період між процедурами ці порушення знову відновлюються.

Оцінюючи ефективність лікування, необхідно враховувати не тільки інтрадіалізні коливання показників уремії, а й їх середні значення, оскільки клінічні прояви уремії значною мірою залежать саме від величини середнього показника [1].

Ознаками адекватного лікування вважають: відносно низький рівень азотемії, близька до стандартної маса тіла, міждіалізна затримка рідини не більше 2,5 - 3 кг, нормальний або незначно підвищений АТ, задовільні показники роботи та розмірів лівого шлуночка серця, повна реверсія перикардиту, рівень гемоглобіну вище від 120 г/л, відсутність ознак невропатії та енцефалопатії.

Удосконалення методів замісної терапії (3Т) XXН, зокрема застосування сучасних діалізних технологій, впровадження в клінічну практику нових методів, що забезпечують адекватне та щадне лікування, як i введення в клінічну практику еритропоетину, забезпечило значне зниження інтеркурентної захворюваності та смертності хворих із ХНН. На перший план виходить проблема якості життя (ЯЖ) таких пацієнтів $[2,3,4]$. Отже, наближення параметрів ЯЖ пацієнтів iз XНH, які отримують замісну ниркову терапію, до рівня їі в популяції здорових стає одним із основних завдань сучасної нефрології. Підхід до вирішення цього важливого питання, як медико-соціальної проблеми, робить актуальним диференційований вибір методу та методики діалізу.

Мета роботи - проаналізувати показники якості життя пацієнтів на діалізі та порівняти їх при викори- станні стандартних та індивідуальних програм лікування.

Матеріал і методи дослідження. Під нашим спостереженням перебувало 36 пацієнтів, які були поділені на 2 групи залежно від програмування сеансів гемодіалізу (діалізної дози, тривалості діалізу тощо).

В першу (основну) групу увійшло 20 пацієнтів, у яких діаліз проводився за індивідуальними програмами, що передбачали тривалість сеансу від 5 до 8 годин, профілювання концентрації натрію, бікарбонату, ультрафільтрації, температури діалізного розчину, індивідуальний підбір швидкості перфузії крові. Другу (контрольну) групу склали 16 пацієнтів, яким застосовували стандартну схему лікування: діаліз їм проводили 3 рази на тиждень по 4 години. Рівень натрію в діалізаті становив 140 ммоль/л, бікарбонату 34 ммоль/л, швидкість перфузії крові - 250 мл/хв.

Вік пацієнтів складав від 36 до 62 років.

Термін перебування на замісній нирковій терапії в основній групі складав: до 90 днів - 1 пацієнт (5 \%), до1 року - 1 людина (5 \%), від 1 року до 5 - найбільша кількість пацієнтів - 11 (55 \%). Пацієнтів із тривалістю діалізу до 7 років - 5 осіб (25\%), до 10 років 1 людина ( $5 \%$ ), більше 10 років - 1 особа (5\%). Варто зазначити, що двоє пацієнтів із тривалістю діалізу до 10 та більше років мали в анамнезі трансплантацію нирки. Таке ж співвідношення тривалості перебування на гемодіалізі спостерігалось і в контрольній групі.

Основними причинами, що призвели до виникнення ХХН були: первинний гломерулонефрит - у 17 осіб (47,2 \%), діабетична хвороба нирок - у 3 (8,3 \%), полікістоз нирок - у 6 (16,7\%), пієлонефрит - у 8 (22,2 \%) пацієнтів. У двох випадках (5,6 \% пацієнтів) причина ХНН не встановлена.

За всіма цими показниками групи були рівнозначними (табл. 1).

Таблиця 1. Основні причини, що призвели до ХНН

\begin{tabular}{|l|c|c|}
\hline \multirow{2}{*}{ Найменування нозології } & \multicolumn{2}{|c|}{ Кількість випадків } \\
\cline { 2 - 3 } & абс. & \% \\
\hline Первинний гломерулонефрит & 17 & 8,2 \\
\hline Діабетична хвороба нирок & 3 & 16,7 \\
\hline Полікістоз нирок & 6 & 22,2 \\
\hline Пієлонефрит & 8 & 5,6 \\
\hline Причина не встановлена & 2 & 100 \\
\hline Всього & 36 & \\
\hline
\end{tabular}

У всіх пацієнтів за загальноприйнятими стандартними методиками визначали міждіалізні показники сечовини, креатиніну, K, Na+ діалізну дозу (KT/V), наявність артеріальної гіпертензії.
Досліджували також клініко-лабораторні показники - загальний аналіз крові (гемоглобін, лейкоцитоз), рівень білка, наявність диспротеїнемії, рівень альбуміну, C-реактивний білок. Всі ці дані визначали при 
використанні стандартної схеми лікування та при проведенні діалізу за індивідуальними програмами і вивчали їх вплив на ЯЖ пацієнтів.

Сьогодні існує понад 60 методик, що дають можливість оцінити різноманітні аспекти якості життя, пов'язані зі здоров'ям. Ми проводили оцінювання за однією з популярних версій опитувальника Kidney Disease Quality of Life Short Form (KDQOL-SFTM) [3]. Статистичну обробку проводили з використанням параметричного критерію Стьюдента, результати вважали достовірними при $р<0,05$.

Результати та їх обговорення. В усіх пацієнтів основної групи була виявлена артеріальна гіпертензія: I ст. не зустрічалась, II ст. - у 14 пацієнтів (70 \%) і Ш ст. - у 6 (30\%) пацієнтів. У всіх пацієнтів із Ш ст. захворювання гіпертензія була не скорегована (АТ- 131/81 мм рт. ст.). Корекція проводилась гемодіалізом, обмеженням харчової солі та вживанням медикаментів. У 4 (20\%) пацієнтів гіпертензія наростала під час діалізу, а в міждіалізний період була скорегованою.

В контрольній групі гіпертензія спостерігалась у 15 пацієнтів, проте хворих із III ст. не було, з II ст. - 11 (73,4 \%) пацієнтів, 3 I ст. - 4 (26,6 \%). Всі випадки були скореговані, корекції домагались гемодіалізом, обмеженням харчової солі та вживанням медикаментів. У 5 випадках (33,3 \%) гіпертензія була скорегованою в міждіалізний період, а під час діалізу наростала.

При визначенні рівня гемоглобіну в основній групі отримали такі дані: до 80 г/л - у 1 пацієнта (5 \%), до 90 г/л - у 5 пацієнтів (25\%), до 100 г/л - у 5 пацієнтів (25\%), від 100 до 110 - у 5 випадках (25\%). У 4 хворих (20,5 \%) анемії не виявлено, гемоглобін у них коливався в межах 114-126 г/л.

У контрольній групі в усіх пацієнтів була виявлена анемія: рівень гемоглобіну коливався від 60 до 110 г/л (до 60 г/л - в 25,5 \% випадків, від 60 до 65 г/л - 6,3\% випадків, від 65 до 80 - 16,5 \%, від 80 до 90 - 6,3\%, від 90 до 100 г/л - 12,5\%, від 100 до 110 - 33,5\%). Лейкоцитозу не виявлено у жодному випадку в обох групах.

Оцінювання фізичного здоров'я пацієнтів проводили за такими параметрами: як пацієнт переносить важкі (біг, підняття тягарів, заняття силовими видами спорту), помірні та незначні фізичні навантаження (ходіння по сходах, прогулянки в декілька кілометрів), відчуття за останні 4 тижні сильного фізичного болю, що заважав виконувати звичайну повсякденну роботу тощо.

Значний вплив на показники ЯЖ пацієнтів мав вік хворих. Як в основній, так і в контрольній групі показ- ники фізичного здоров'я були нижчі у віковій групі після 50 років і складали: 39,5 \% пацієнтів в основній групі та 35,9% у контрольній, на відміну від пацієнтів віком до 50 років, де цей показник був значно вищим: $44 \%$ та 39,4\% відповідно.

При аналізі показників фізичного здоров 'я у пацієнтів основної групи (яким проводили діаліз за індивідуальною методикою) виявились позитивні тенденції. Так, математичне очікування в основній групі дорівнювало $\mathrm{M} \pm \mathrm{T}=41,6 \pm 3,6 \%$, тоді як у контрольній $\mathrm{M} \pm \mathrm{T}=35,7 \pm 3,6 \%$ (проте, $\mathrm{p}>0,05$ ).

Значної різниці в показниках залежно від тривалості замісної ниркової терапії ми не виявили, хоча також визначено деяку тенденцію до більш високого оцінювання свого здоров'я в майбутньому у пацієнтів, які перебувають на діалізі більше 1 та до 5 років в обох групах. У жодній із груп не виявлено також статистично значимої залежності оцінки свого фізичного статусу від статі. Стосовно зв'язку оцінки фізичного стану з патологією, що призвела до ХНH, то вона значно нижча у пацієнтів із діабетичною хворобою нирок, хоча говорити про статистичну значимість цих показників не доводиться через малу кількість спостережень. Не можна ігнорувати й факт впливу на стан здоров'я і самого цукрового діабету.

Для оцінювання психічного здоров'я використовували такі пункти опитувальника: емоційний стан викликав труднощі у виконанні роботи чи іншій повсякденній діяльності, наскільки емоційний стан протягом останніх 4 тижнів заважав проводити час із сім'єю, друзями, сусідами чи в колективі, чи відчували себе пацієнти бадьорими, чи сильно нервували, відчували себе повними сил та енергіï, чи мали відчуття щастя тощо, а також включали питання щодо очікувань погіршення здоров'я.

Аналіз середніх показників психічного здоров'я, котрі характеризують якість життя пацієнтів виявив, що серед пацієнтів, яким замісна терапія проводилась за індивідуальною програмою, були вищими, так як і фізичні показники, а саме: $\mathrm{M} \pm \mathrm{T}=46,0 \pm 1,8 \%$. Різниця між показниками в двох групах виявилась достовірною $(\mathrm{p}<0,05)$.

При самостійній оцінці стану здоров'я $9 \%$ пацієнтів основної групи оцінили його як відмінно, як добре $61 \%$ і у 30 \% випадків, як посереднє. У контрольній групі відмінним своє здоров'я не вважав жоден із пацієнтів, 61 \% - вважали його добрим і 15,4% Хворих оцінили його як задовільне. Решта пацієнтів не змогли визначитись.

Отже, основна маса пацієнтів у обох групах оцінювала стан здоров'я як добрий. 
Лише в двох випадках на питання про погіршення здоров'я у майбутньому пацієнти з контрольної групи відповіли ствердно. Серед пацієнтів основної групи таких не було.

Оцінюючи зв'язок гематологічних показників із показниками якості життя можна допустити думку про те, що вищий рівень їх в основній групі впливає на покращення ЯЖ пацієнтів. Це вимагає більш детального вивчення й окремого аналізу.

Висновки. У хворих із ХХН, які отримують ниркову замісну терапію, відмічається зниження якості життя. Проведення діалізу за індивідуальними про-

\section{Лтература}

1. Лукичев Б. Г. Гемодиализный больной - проблема амбулаторного лечения / Б. Г. Лукичев // Новые Санкт-Петербургские Врачебные Ведомости. - 2000. - №2 3. - С. 45-48.

2. Васильева И. А. Особенности качества жизни больных с хронической почечной недостаточностью при лечении гемодиализом / И. А. Васильева // Известия Российского государственного педагогического университета им. А. И. Герцена. - 2008. - №> 57. - С. 75-86. грамами сприяє покращенню якості життя пацієнтів, зокрема, появі тенденцій покращання середніх значень ЯЖ за всіма показниками, включаючи психічну складову здоров'я (поліпшення емоційного стану хворих, їх соціальна адаптація тощо).

Все це викликає необхідність подальшого вивчення зв'язку уремічних, гематологічних показників, їх кореляційних зв'язків із показниками якості життя, кластеризації груп спостереження. Саме в такому випадку стане можливим розроблення математичних моделей індивідуальних програм діалізу, що, безумовно, вплине на прогноз виживання хворих, успішність їх реабілітації.

3. Васильева И. А. Российская версия опросника Kidney Disease Quality of Life - Short Form (KDQOL-SFTM) - ценного диагностического инструмента для оценки качества жизни больных на диализе / И. А. Васильева // Нефрология. -2007. - №> 11. - С. 64-70.

4. Bergner M. The Sickness Impact Profile: Development and final revision of a health status Measure / M. Bergner// Medical Care. - 1981. - V 19, №> 8. - P. 787-805. 